\title{
ZASTOSOWANIE KOMPUTEROWEGO ŚRODOWISKA NA POTRZEBY TWORZENIA MATERIAŁÓW SZKOLENIOWYCH Z ZAKRESU BEZPIECZEŃSTWA PRACY WYBRANYCH MASZYN STACJONARNYCH
}

\begin{abstract}
W artykule przedstawiono opracowaną w CIOP-PIB metodę wykorzystania najnowszych technik modelowania i wizualizacji na potrzeby tworzenia materiałów szkoleniowych w przemyśle metalowym i drzewnym. Metoda ta oparta jest na wykonanych wizualizacjach obrazujących zagrożenia mechaniczne powstałe podczas użytkowania maszyn do obróbki skrawaniem metalu oraz drewna. Z punktu widzenia psychologii jest wiadome, że obrazy zapamiętuje się lepiej niż słowa, dlatego też opracowane wizualizacje są doskonałym uzupełnieniem szkoleń z zakresu BHP. Treści prezentowane $\mathrm{w}$ wizualizacjach odnoszą się zarówno do prawidłowego, jak i nieprawidłowego przebiegu czynności roboczych związanych z użytkowaniem maszyn. Każda wizualizacja składa się z dwóch części. W pierwszej części przedstawiono nieprawidłowe czynności prowadzące do zaistnienia zdarzenia wypadkowego wraz z niezbędnym komentarzem, w drugiej zaś prawidłowe działania (czynności) ograniczające lub eliminujące ryzyko zaistnienia zdarzenia.
\end{abstract}

Słowa kluczowe: ryzyko wypadkowe, bezpieczeństwo, techniki wizualizacji

\section{Wprowadzenie}

Ponad $80 \%$ wypadków w przemyśle metalowym lub drzewnym jest związanych z obsługą maszyn. Ze względu na charakter pracy podczas obsługi maszyn do obróbki skrawaniem (możliwość kontaktu operatora z ostrymi i ruchomymi elementami), jak i charakter samych wypadków (często są to wypadki ciężkie), zastosowanie wirtualnego środowiska jest często jedyną dostępną metodą zobrazowania przyczyn i przebiegu wypadków mogących występować podczas użytkowania tych maszyn. Jako materiał w wizualizacjach wykorzystano sześć reprezentatywnych maszyn: tokarkę uniwersalną (rys. 1.), wiertarkę kolumnową, szlifierkę stołową, prasę mechaniczną mimośrodową, pilarkę tarczową i pilarkę taśmową. Wybór tych maszyn był podyktowany ich różnorodnym zastosowaniem i użytkowaniem oraz tym, że są to obrabiarki konwencjo- 
nalne, obsługiwane ręcznie, tj. operator ręcznie za pomocą elementów sterowniczych inicjuje lub zatrzymuje ruch roboczy narzędzia obrąbiającego, ręcznie ustawia przedmioty itp. [1]. Z tego względu maszyny te są źródłem wielu zagrożeń mechanicznych, takich jak pochwycenia, wciagnięcia, skaleczenia, przebicia, zmiażdżenia, obcięcia itp.

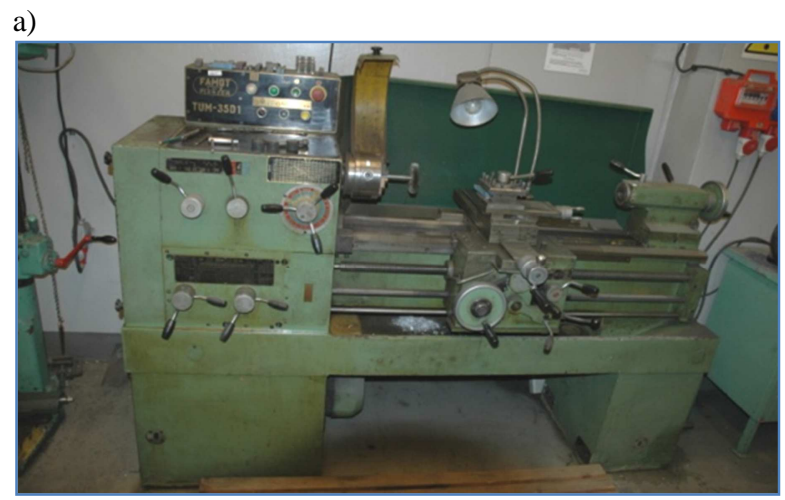

b)

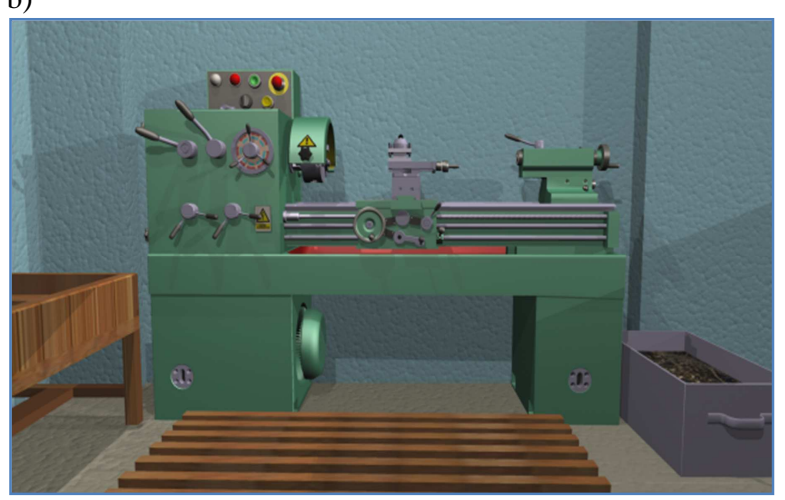

Rys. 1. Tokarka TUM 25 na stanowisku pracy: a) obiekt rzeczywisty, b) model komputerowy

Fig. 1. Lathe TUM25 at a workstation: a) real object, b) computer model

Przed przystapieniem do wykonania komputerowego środowiska, a w rezultacie do wizualizacji należało dokładnie zapoznać się ze środowiskiem pracy warsztatu mechanicznego (rys. 2.) i stolarni, a także z zagrożeniami związanymi $\mathrm{z}$ użytkowaniem wspomnianych maszyn. W tym celu zebrano niezbędną dokumentację obejmującą:

- analizę wypadków powstałych podczas użytkowania wymienionych maszyn, dostępnych w bazie danych OSHA (Safety and Health Administra- 
tion, U.S. Department of Labour), Państwowej Inspekcji Pracy oraz GUS-u,

- dokumentacje technologiczne, DTR oraz instrukcje BHP,

- dokumentację szkicową, pomiarową i fotograficzną odwzorowywanych pomieszczeń pracy wraz z wyposażeniem,

- sekwencje filmowe i dźwiękowe środowiska pracy oraz czynności wykonywanych przez pracowników stolarni i warsztatu mechanicznego.

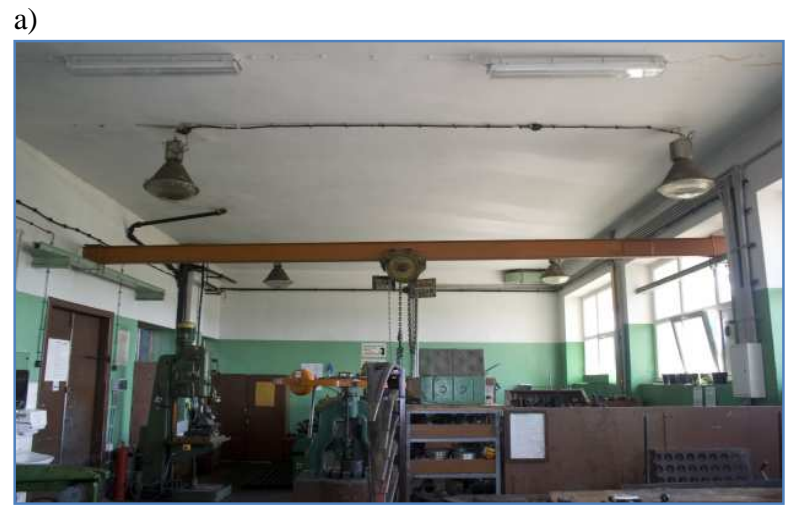

b)

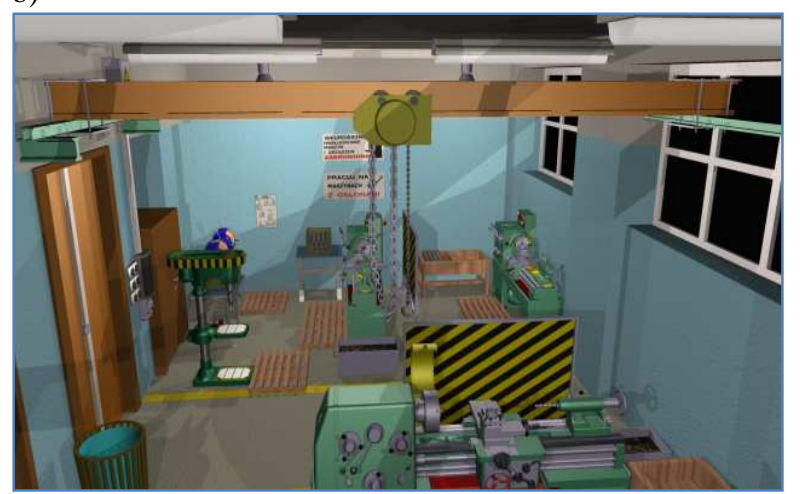

Rys. 2. Pomieszczenie warsztatu mechanicznego: a) widok rzeczywisty, b) środowisko komputerowe wykonane na potrzeby wizualizacji

Fig. 2. Machine workshop: a) real view, b) computer generated environment for the visualization purposes

Na podstawie tak zebranej dokumentacji sporządzono schemat postępowania podczas tworzenia wizualizacji zagrożeń mechanicznych (rys. 3.), który pozwolił na opracowanie wizualizacji na potrzeby wzbogacenia materiałów szkoleniowych. 


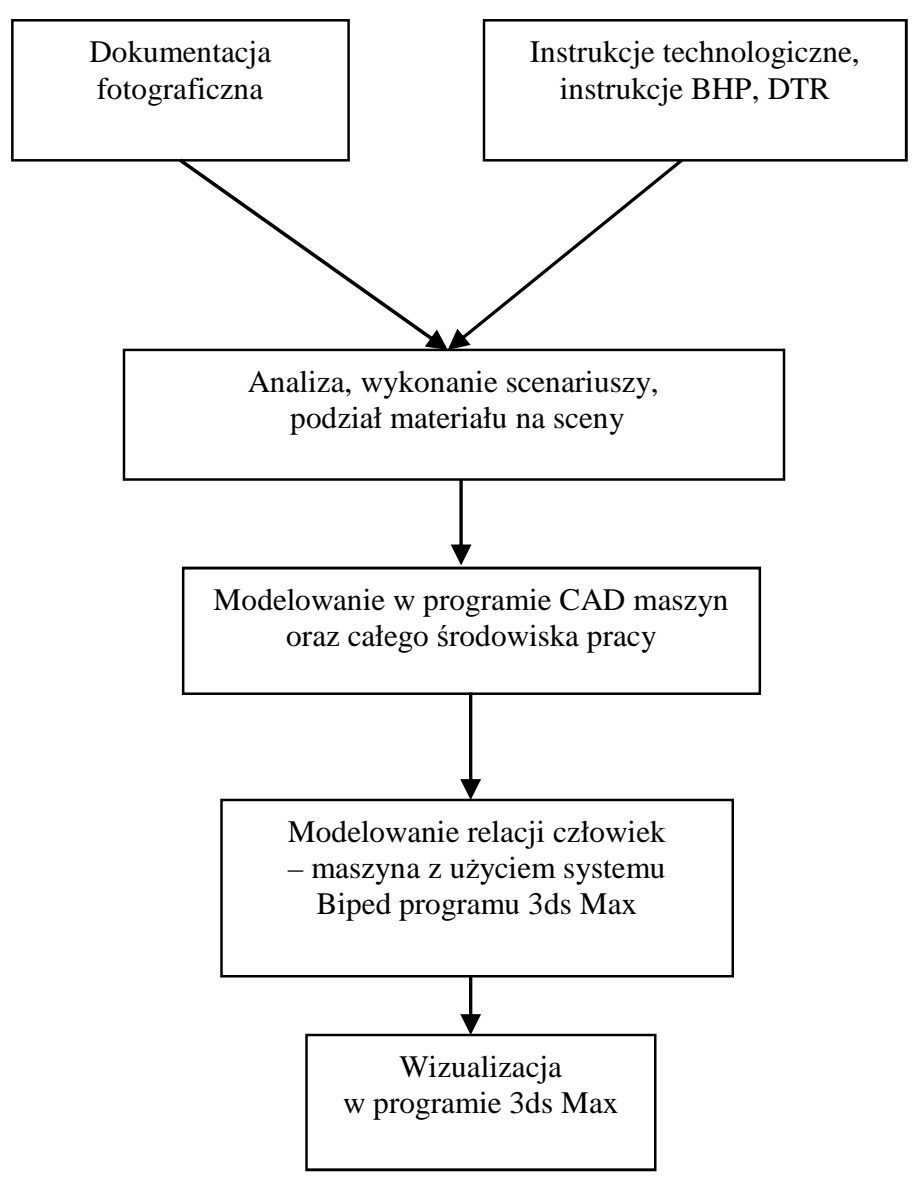

Rys. 3. Schemat przebiegu procesu tworzenia wizualizacji

Fig. 3. Scheme presenting the process of creating the visualization

\section{Wizualizacje zagrożeń mechanicznych}

Zebrany materiał posłużył do napisania scenariuszy, na podstawie których powstało dziesięć wizualizacji o następujących tytułach:

1. Skaleczenie na skutek kontaktu z ruchomą piłą taśmową.

2. Uderzenie na skutek odrzutu ciętej deski na pilarce tarczowej.

3. Pochwycenie ręki pracownika przez obracający się uchwyt tokarski.

4. Pochwycenie części ciała pracownika przez obracający się uchwyt tokarski.

5. Wyrzut noża tokarskiego z imaka.

6. Zmiażdżenie ręki pracownika podczas obsługi prasy mechanicznej.

7. Zmiażdżenie palców dłoni w wyniku upadku obrabianego przedmiotu. 
8. Uraz dłoni pracownika wskutek kontaktu ze ściernica.

9. Uraz części ciała pracownika związany z rozwiercaniem otworów w przedmiocie trzymanym oburącz.

10. Uraz ręki wskutek sięgania przez strefę roboczą wiertarki po obrabiany przedmiot.

Każdy ze scenariuszy, a co za tym idzie każda wizualizacja składa się z dwóch części ukazujących najpierw nieprawidłowe działanie pracownika prowadzące do wypadku, a następnie prawidłowy sposób wykonywania przez niego pracy. Ponadto poszczególne części scenariuszy zostały podzielone na sceny, których liczba zależy od rodzaju oraz złożoności prezentowanego zdarzenia wypadkowego. W początkowych scenach każdej wizualizacji jest ukazywane pomieszczenie oraz uraz, jakiego doznał pracownik w tym pomieszczeniu na skutek zaistniałego wypadku. Dopiero potem zaczynają się właściwe sekwencje filmowe ukazujące czynności wykonywane przez pracowników oraz urazy powstające wskutek zaistnienia zagrożeń mechanicznych (rys. 4.). W sekwencjach tych znajdują się również plansze z informacjami odnośnie rodzaju zagrożenia mechanicznego, na jakie jest narażony pracownik. Natomiast w sekwencjach składających się na drugą część filmu, poza wcześniej wspomnianymi sytuacjami przedstawiającymi sposoby prawidłowo wykonywanych czynności, znajdują się również ekrany informacyjne wyświetlające rodzaje zastosowanych środków ochronnych mających na celu zmniejszenie lub wyeliminowanie ryzyka zaistnienia tych zdarzeń.

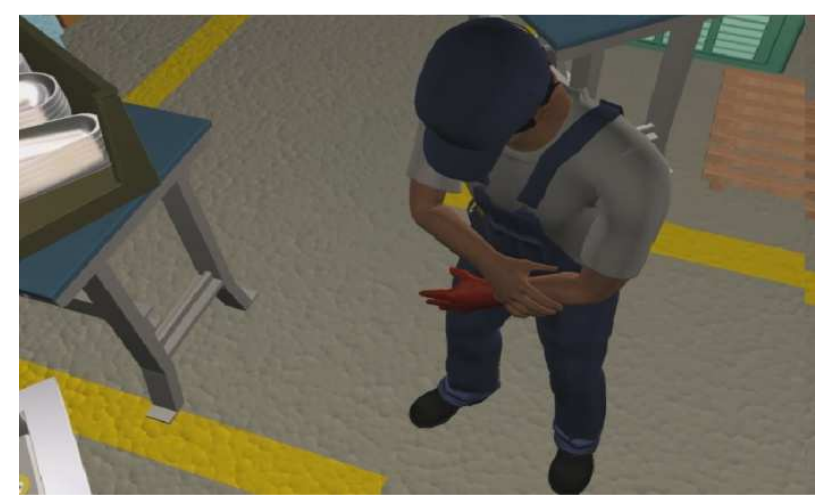

Rys. 4. Fragment przykładowej sceny przedstawiającej uraz pracownika na skutek zgniecenia przez poruszający się stempel prasy mechanicznej

Fig 4. Fragment of a scene illustrating an injury suffered by an employee as a result of crush by mechanical press stamp

Aby lepiej uzmysłowić oglądającym niebezpieczeństwo związane z obsługą maszyn stacjonarnych od obróbki skrawaniem, a szczególnie zagrożenie wyni- 
kające $\mathrm{z}$ kontaktu $\mathrm{z}$ będącymi w ruchu elementami maszyn, przedmiotów, narzędzi itp., wizualizacje zostały uzupełnione o animowane (pojawiające się na tle obrazu) wektory ruchu elementów (rys. 5.) mogących stanowić zagrożenie dla operatora maszyny lub osoby znajdującej się w pobliżu. Ponadto do wektorów tych dodane są również wartości, np. prędkości obrotowej wrzeciona. Wartości te lepiej obrazują prędkości, z jakimi mają do czynienia operatorzy maszyn skrawających podczas pracy. W wielu przypadkach prędkości te nie są widoczne, gdyż niejednokrotnie pojawia się złudzenie, że przedmiot stoi w miejscu, gdy tak naprawdę obraca się ze znaczną szybkością. Często na potrzeby generowania obrazu (renderu) prędkość ta była celowo zmniejszana, aby można było zaobserwować ruch danego obiektu. Dotyczy to również ruchów wzdłużnych, nawet gdy bez pojawiających się napisów nie można by było ocenić, z jaką prędkością przedmiot się przemieszcza lub zostaje wyrzucony.

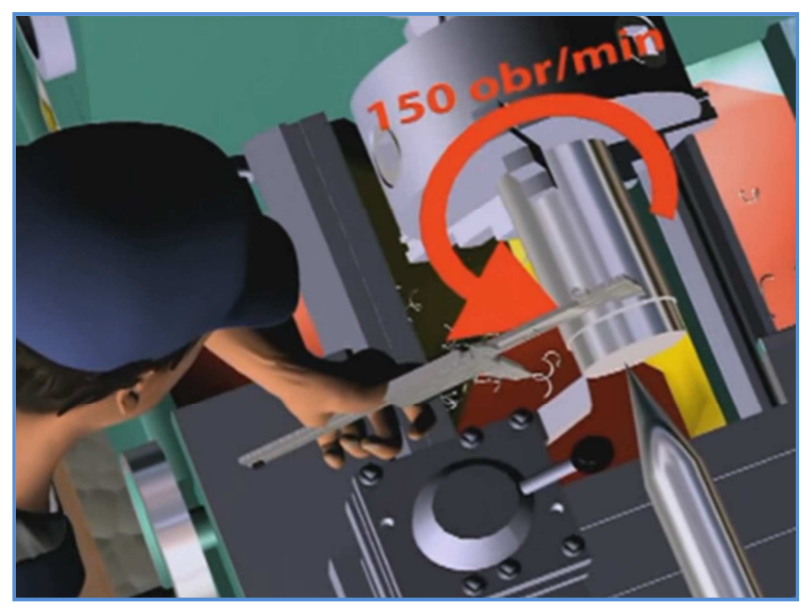

Rys. 5. Wektor ruchu obrotowego wrzeciona tokarki wraz z podaną wartością prędkości obrotowej podczas toczenia metalowej części

Fig. 5. Rotation vector of lathe spindle together with a value of rotation speed during rolling of a metal element

Ważnym elementem tworzenia wizualizacji było modelowanie obiektów [2-4], w tym maszyn biorących udział w wizualizacjach oraz ich części. Do tego celu została wykorzystana głównie dokumentacja szkicowa pomiarowa i fotograficzna środowiska pracy, ale również instrukcje użytkowania maszyn DTR itp. Modelowanie odbywało się za pomocą programów 3ds Max oraz CATIA, z tym że w tym drugim przypadku konieczne było zaimportowanie obiektów do programu 3ds Max. Zwrócono szczególną uwagę na wierne odwzorowanie maszyn biorących udział w zdarzeniach wypadkowych z uwzględnieniem parame- 
trów geometrycznych, materiałów oraz tekstur nadających kształty i wygląd. Natomiast modele drugiego planu zostały wykonane z pewnym odstępstwem od rzeczywistych wzorców, ale z zachowaniem odpowiedniej dbałości o szczegóły.

Modelowanie postaci ludzkich oraz odwzorowanie ruchów części ciała [5] były najważniejszymi i najtrudniejszymi elementami procesu wizualizacji. Do tego celu wykorzystano znajdujący się w programie 3ds Max system kości Biped (rys. 7.), który umożliwiał wstawienie tzw. „skóry” i połączenie z nią za pomocą modyfikatora Physique poszczególnych fragmentów modelu człowieka. Użycie tego systemu znacznie ułatwiło animacje postaci, gdyż Biped, jako gotowy szkielet przeznaczony do animacji istot dwunożnych, posiada odpowiednio zhierarchizowane kości i nadane ograniczenia na stawy umożliwiające poruszanie fragmentów modelu w sposób zgodny z anatomicznymi ograniczeniami człowieka.

Ponieważ podczas prac nad wizualizacjami zagrożeń mechanicznych często zachodziła konieczność wykonywania przez postać pracownika ruchów związanych z czynnościami obsługi maszyn, a więc chwytania różnego rodzaju przedmiotów (np. narzędzi, dźwigni, uchwytów), sztandarowy system kości Biped należało uzupełnić o dodatkowe kości palców rąk. Następnie za pomocą tzw. krzywych deformacji modyfikatora Physique trzeba było określić zakres oddziaływania elementów kości na odpowiadające im fragmenty „skóry” (rys. 7c). Proces ten dotyczył całego modelu postaci, szczególnie takich części, jak palce, ale ze względu na niewielkie odległości pomiędzy poszczególnymi kośćmi był trudny do przeprowadzenia. Każde nieodpowiednie ustawienie zakresu oddziaływania krzywych deformacji wiązało się $\mathrm{z}$ występowaniem niepożądanego efektu tzw. ciągnących się wierzchołków „skóry” (rys. 6.).

Rys. 6. Przykładowy efekt ciagnących się wierzchołków „skóry” Fig. 6. The example of effect of pulling of ,skin” vertexes

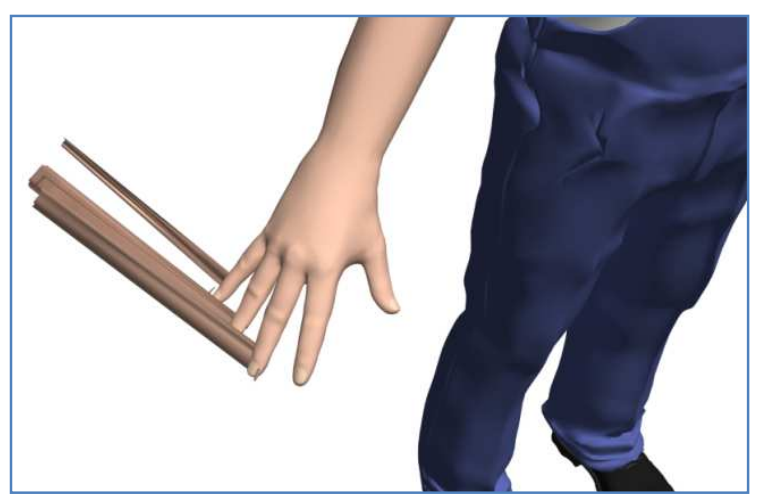

Podczas animowania tego typu chwytania przedmiotów pomocne było również użycie tzw. kinematyki odwrotnej $[3,6,7]$, a szczególnie takich narzędzi, jak choćby znajdujące się w 3ds Max narzędzie IK Ben. Za jego pomocą 
przedmioty można przykleić do różnych wybranych części ciała animowanej postaci, i w ten sposób, animując ruch (np. dźwigni wiertarki), poruszać ręką, a nie odwrotnie, tak jak się to dzieje w rzeczywistości. Z punktu oglądającego efekt animacji nie ma to jednak znaczenia.

a)

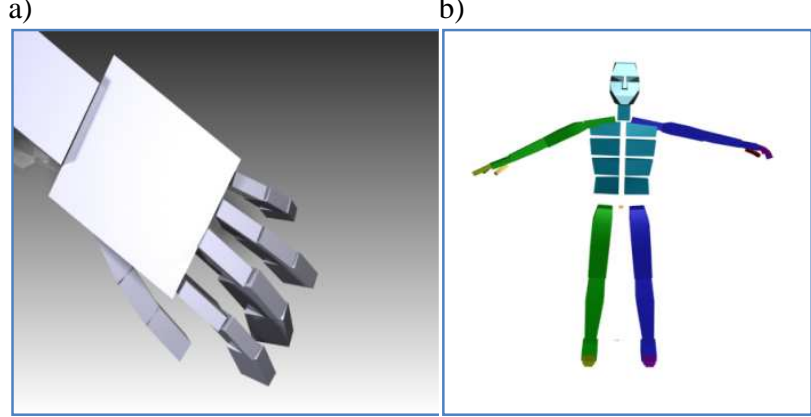

c)

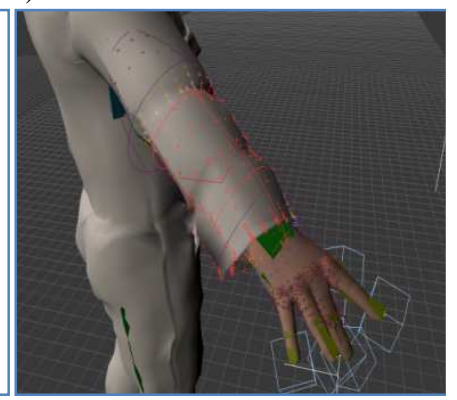

Rys. 7. Model postaci człowieka z wykorzystaniem systemu Biped: a) kości dłoni, b) szkielet całej postaci, c) zakres oddziaływania krzywych deformacji

Fig. 7. Model of a human body with the use of the Biped system: a) bones of the hand, b) skeleton of the whole body, c) scope of the influence of deformation curves

Aby podnieść realizm przedstawionych scen, a tym samym zwiększyć oddziaływanie na potencjalnych odbiorców, do wizualizacji należałoby dodać ścieżkę dźwiękową. W ramach realizacji zadania w środowiskach pracy hali przemysłowej i stolarni zostały zarejestrowane zarówno filmy ukazujące czynności wykonywane przez pracowników obsługujących maszyny prezentowane w wizualizacjach, jak i same sekwencje dźwiękowe związane z tymi czynnościami, np. dźwięki przełączania elementów sterowniczych, uruchamiania i zatrzymywania maszyn, odkładania i pobierania przedmiotów i narzędzi, mocowania przedmiotów od obróbki, dźwięki pracy maszyn, odgłosy podczas skrawania obrabianych przedmiotów. Zarejestrowane zostały również dźwięki, których źródłem byli ludzie, np. kroki przechodzących pracowników czy też okrzyki bólu po zaistniałym zdarzeniu wypadkowym. Tak uzyskany materiał dźwiękowy został następnie obrobiony do właściwego formatu i dopasowany z użyciem odpowiedniego oprogramowania (np. Pinnacle Studio) do długości poszczególnych sekwencji wizualizacji w trakcie montażu wizualizacji.

\section{Podsumowanie}

Wizualizacje zagrożeń mechanicznych mogą być bardzo ważnym uzupełnieniem szkoleń z zakresu bezpieczeństwa użytkowania maszyn stacjonarnych. Mogą w sposób dodatni wpłynąć na poszerzenie wiedzy na temat przyczyn 
i okoliczności zaistnienia wypadków, będących wynikiem konkretnego zagrożenia mechanicznego występującego podczas pracy. Prawidłowo wykonaną wizualizację powinno cechować jak najwierniejsze oddanie środowiska pracy oraz jak najbardziej precyzyjne pokazanie ruchów czynności wykonywanych przez pracowników podczas obsługi maszyn, a także momentu samego zdarzenia i związanych z nim konsekwencji, czyli urazów operatora na skutek zagrożeń mechanicznych, np. pochwycenia, wciągnięcia, uderzenia, zgniecenia, zmiażdżenia, przebicia, odcięcia. Szczegółowe wykonanie środowiska wymaga często długotrwałego modelowania, co znacznie wydłuża proces wykonania całej wizualizacji i jest jednocześnie większym obciążeniem dla systemu, powodując nawet $\mathrm{w}$ skrajnych przypadkach jego zawieszanie się. W tej kwestii należy zawsze starać się uzyskać kompromis, gdyż zbyt duże uproszczenia znacznie obniżają wiarygodność wizualizacji i w ujemny sposób wpływają na przyswajanie przekazywanej treści.

Aby materiały szkoleniowe przyniosły jak największe korzyści, równie ważnym zagadnieniem (oprócz ich jakości) jest sposób ich rozpowszechniania, umożliwiający dotarcie do jak największej liczby odbiorców. Wizualizacje zagrożeń mechanicznych dzięki infrastrukturze informatycznej CIOP-PIB są dostępne od stycznia 2012 r. na stronie internetowej www.ciop.pl i mogą być prezentowane $\mathrm{z}$ wykorzystaniem dowolnego sprzętu komputerowego. Jednak na oglądających większe wrażenie robi ich prezentacja na dużym ekranie, zwłaszcza $\mathrm{z}$ użyciem odpowiedniego sprzętu w wersji stereo. Więcej na temat powstałych wizualizacji zagrożeń mechanicznych powstających podczas użytkowania maszyn do obróbki skrawaniem metalu oraz drewna można dowiedzieć się z publikacji $[2,8]$.

\section{Literatura}

[1] Poradnik warsztatowca mechanika, WNT, Warszawa 1981.

[2] Kalwasiński D., Filipek D.: Opracowanie wizualizacji zdarzeń wypadkowych występujących podczas użytkowania maszyn stacjonarnych, Mechanik, 7/2012, 598/325-332.

[3] Pasek J.: Modelowanie i animacja w 3ds Max, HELION, Gliwice 2007.

[4] Kelly L.: Murdock 3ds Max 2009 - Biblia, HELION, Gliwice 2009.

[5] Atlas miar człowieka. Dane do projektowania i oceny ergonomicznej, CIOP, Warszawa 2001.

[6] Pasek J.: 3ds Max. Animacja od podstaw - Profesjonalne przygotowanie do tworzenia grafiki i animacji, HELION, Gliwice 2007.

[7] Kennedy S., Maestri G., Frantz R.: 3D Studio Max - Czarna księga animatora, HELION, Gliwice 1998.

[8] Kalwasiński D., Filipek D.: Multimedialne wizualizacje zagrożeń mechanicznych związanych z użytkowaniem maszyn w przemyśle metalowym, Bezpieczeństwo Pracy, 11/2011, 14-17. 


\title{
APPLICATION OF COMPUTING ENVIRONMENT FOR DEVELOPING INSTRUCTIONAL MATERIALS IN THE FIELD OF WORKING SAFETY OF STATIONARY MACHINES
}

\author{
A bstract
}

The paper presents the method of using the latest modeling and visualization techniques for the purposes of developing instructional materials in the metal and woodworking industry. The method was elaborated in CIOP-PIB. It is based on visualizations illustrating mechanical hazards which arise when using metal and wood processing machinery. From the psychological point of view, it is commonly known that pictures are remembered better than words. Therefore, the visualizations are a perfect supplement for trainings in the area of occupational safety and health. Information presented with the aid of visualizations pertain to both proper and improper process of work activities connected with the use of machines. Each visualization consists of two parts. The first part presents incorrect actions leading to an accident and is accompanied by the necessary comment. The second part presents correct actions which reduce or eliminate risk of an accident.

Keywords: risk of an accident, safety, visualization techniques

DOI: $10.7862 / \mathrm{rm} .2012 .1$ 